\title{
ANALYSIS OF LAND USE CHANGE IN INNER MONGOLIA REGION FROM 1978 TO 2018 BASED ON REMOTE SENSING
}

\author{
Wei Qu ${ }^{1,2}$, Yuan Yao ${ }^{1,2}$, Zhiguo Pang ${ }^{1,2}$, Jingxuan Lu $^{1,2}$, Kun Yang $^{1,2}$, Xiaotao Li ${ }^{1,2}$, Lin Li ${ }^{1,2}$, Wei Jiang ${ }^{1,2}$, June Fu ${ }^{1,2}$, Tianjie Lei ${ }^{1}$ \\ ${ }^{1}$ China Institute of Water Resource and Hydropower Research, Beijing 100038 - (quwei, yaoyuan, pangzg, lujx, yangkun, lixt, lilin, \\ jiangwei, fuje, leitj)@iwhr.com \\ ${ }^{2}$ Research Center on Flood \& Drought Disaster Reduction of the Ministry of Water Resources, Beijing 100038
}

\section{TCIII-7: Landuse and Landcover Change Detection}

KEY WORDS: Inner Mongolia, Remote sensing, Land use, Change characteristics, 40years

\begin{abstract}
:
Land use change is an important theme of the research on the impact of human interaction on global change. In this paper, two phases of land use data were interpretated from remote sensing images of 1978 and 2018, and the spatial-temporal characteristics of land use change in China's Inner Mongolia Region from 1978 to 2018 were analyzed. The results indicated that grasslands and arable land are mainly distributed in the central and eastern region of Inner Mongolia, forest land are mainly distributed in the eastern region, and unused land is mainly distributed in the western region. From 1978 to 2018, the area of arable land in Inner Mongolia decreased by $9,000 \mathrm{~km}^{2}$, forest land increased by $900 \mathrm{~km}^{2}$, and the area of grassland decreased by $1,400 \mathrm{~km}^{2}$. Urban and rural, industrial mines, and residential land continued to increase with an area of $7,800 \mathrm{~km}^{2}$; and unused land increased by an area of $11,500 \mathrm{~km}^{2}$. It was indicated that after 40 years of development, land use in urban and rural areas, industrial mines, and residential areas caused by human activities in the Inner Mongolia Region has increased significantly. At the same time, the policy of returning farmland to forests to protect the environment has achieved significant results.
\end{abstract}

\section{INTRODUCTION}

Land use and land cover changes (LUCC) is one of the core project of the International Geosphere-Biosphere Programme (IGBP) and the International Human Dimension Programme on Global Environmental Change (IHDP). It is a hot and frontier issue in the research of global environment. LUCC contribute to qualitive and quantitative analyse the impacts of human activities on climate change, water and soil erosion, hydrological process and ecosystem function. Domestic and foreign scholars successively carried out many related researches.

The Inner Mongolia is located in the northern frontier of China. As a significant ecological barrier in northern China, it has one of the four prairies in this country and distributes a third of China's desert and sandy land. The Inner Mongolia is affected by soil erosion due to abundant sources of sand and frequent gale weather. The economic development aggravates the burden of the ecosystem by the high intensity of human activities and the drastic change of land types. The Reform and Opening in 1978 can be called the third enormous historical change in the 20th century. It is of great historical significance to backtrack on the land use situation at that time. Analysis of land use changes in the 40 years of reform and opening up can help systematically grasp the overall layout and changes of land use in Inner Mongolia.

In view of this, based on remote sensing image data, this paper builds the two-stage land use data sets of the Inner Mongolia in 1978 and 2018, quantitative analyses layout and characteristics of land use changes, and reveals the spatial-temporal changes of land use, provides a scientific basis for the rational development and utilization of land resources and the analysis of soil and water loss in the region.

\section{STUDY AREA}

The Inner Mongolia (Figure 1) is located in the northern frontier of China $\left(37^{\circ} 24^{\prime}-53^{\circ} 23^{\prime} \mathrm{N}, 97^{\circ} 12^{\prime}-126^{\circ} 04^{\prime} \mathrm{E}\right), 2400$ kilometres long from east to west and 1700 kilometres wide from north to south. The Inner Mongolia crosses the northwest, north and northeast China. It is adjacent eight provinces, including Heilongjiang, Jilin and Liaoning provinces to the east, Gansu to the west, Hebei, Shanxi, Shanxi, and Ningxia to the south, and Mongolia and Russia to the north. It administers 9 cities and 3 leagues, occupies $12.3 \%$ of China's land area.

In this area, the terrain is complex, mainly composed of mountains, hills and plateaus. The topography gradually declines from south to north and west to east. The climate is dominated by temperate continental monsoon climate. From east to west, it spans five climatic zones: temperate humid zone, semi-humid zone, semi-arid zone, arid zone and extreme arid zone. Thus, the Inner Mongolia forms a diverse geographical environment and rich natural resources. The land use policy of the Inner Mongolia has been continuously adjusted during the years of social development. From the large-scale reclamation of grasslands and woodlands to meet the "food for the program" policy, to conversion of cropland to forest and grassland for "ecological first". Both land use intensity and methods have changed tremendously. Land use patterns have changed significantly, and have had different effects on ecosystem patterns and processes. 


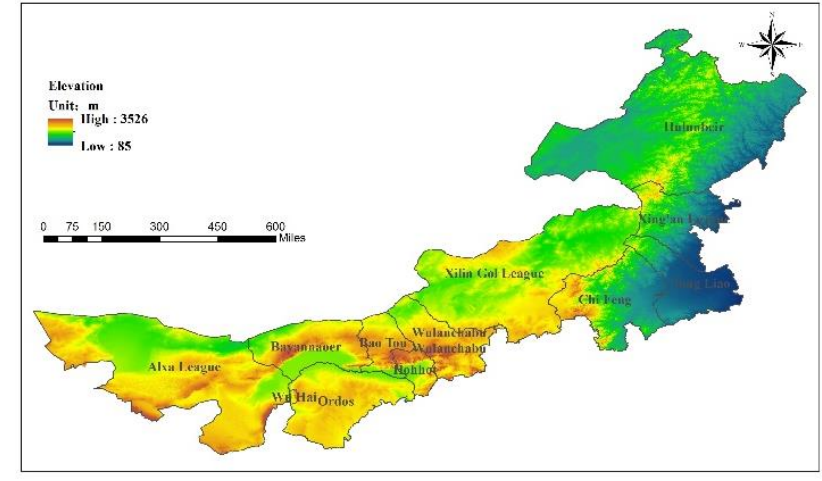

Figure 1. Location and topography of the study area

\section{DATA AND METHODS}

\subsection{Remote sensing data}

The remote sensing data are mainly from LandsatMSS/TM/ETM and Landsat8 images which covered the whole region. The area that cannot be covered due to poor or lack of time are supplemented by the data of China-Brazil earth resource satellite or HJ satellite. The LULC data are mainly from two Landsat images (Landsat-MSS (1978), Landsat8 images (2018) In seasonal aspects, cloudless images (cloud measurement $<10 \%$ ) were selected from middle of June to end of September.

\subsection{Methods}

\subsubsection{Data processing and interpretation}

Data processing mainly includes band extraction, false colour composite, geometric exact correction, and image mosaic by counties. The geometric exact correction process is using a topographic map of China (scale-1:100,000) as the standard, correcting the first completed remote sensing data, and then using the corrected remote sensing data to correct other image data. The LUCC thematic data of China (scale-1:100,000) is based on albers equal area conic. Therefore, the coordinates and projection parameters use the albers equal area conic when correct these remote sensing images.

In the process of land use interpretation, first, the geometric shapes, colour and texture features, and spatial distribution of each land use/cover type are analysed combining with the expert knowledge, the spectral characteristics of the images and field observed data. Then referring related geographic maps to build interpretation marks. The accuracy of the interpretation result is as follows: the correct rate of croplands, urban and rural settlements is all not less than $95 \%$, the correct rate of grasslands, forest and water bodies is not less than $90 \%$, that of unused land is not less than $85 \%$. During the mapping process, vector line segments representing land use/cover types cannot exceed two pixels in the original image. 2 land use / coverage data sets for study area are generated under strict quality control.

\subsubsection{LUCC characteristics analysis method:}

(1) The rate of land use change. The dynamic degree of a certain land use type refers to the quantity change of this land use type within a period of time in the study area. It can quantitatively describe the changing speed of this land use type within a certain time in the area. The dynamic degree is calculated by

$$
\begin{gathered}
K_{T}=\frac{U_{b}-U_{a}}{U_{a}} \times 100 \% \\
K=\frac{U_{b}-U_{a}}{U_{a}} \times \frac{1}{T} \times 100 \%
\end{gathered}
$$

where $\quad K=$ the dynamic degree of a certain land use type

$\mathrm{U}_{\mathrm{a}}, \mathrm{U}_{\mathrm{b}}=$ the area of the initial and end of the study

$\mathrm{T}=$ the length of the study period (If the unit scale of $\mathrm{T}$ is set to year, the value of $\mathrm{K}$ is the annual change rate of the land use type) the study period

$K_{T}=$ the dynamic degree of this land use type during

(2) Transfer matrix of land use. The Markov land use transfer matrix is used to overlay and analyse the grid land use / cover data of two periods. Then obtain the dynamic processing of each land-use type transformation in this period. While for the transfer matrix:

$$
\begin{gathered}
\mathrm{S}=\left[\begin{array}{cccc}
S_{11} & S_{12} & \ldots & S_{1 n} \\
S_{21} & S_{22} & \ldots & S_{2 n} \\
\ldots & \ldots & \ldots & \ldots \\
S_{n 1} & S_{n 2} & \ldots & S_{n n}
\end{array}\right] \\
D_{i}=\sum_{j=0}^{n} S_{i j}-S_{i i} \\
D_{j}=\sum_{i=0}^{n} S_{i j}-S_{j j}
\end{gathered}
$$

where $\quad n=$ the number of land use types

$i, j(i, j=1,2,3 \ldots, \mathrm{n})=$ the types of land use

$S_{i j}=$ Area of land types converted at the beginning of

the study $(i)$ into land types at the end $(j)$

$D_{i}=$ reduced area of $i$ land type

$D_{j}=$ increased area of $j$ land type

The land-use net change $\left(G_{j}\right)$ is the absolute difference between transfer-out and transfer-in area in the matrix of land use.

$G_{j}=\max \left(S_{j+}-S_{j j}, S_{+j}-S_{j j}\right)-\min \left(S_{j+}-S_{j j}, S_{+j}-S_{j j}\right)=$ $\left|S_{+j}-S_{j+}\right|$

where $G_{j}=$ the net change of the j-th land-use type

$S_{j+}=$ the transfer-out of land use type

$S_{+j}=$ the transfer-in of land use type

The concept of land use type exchange $\left(C_{j}\right)$ is introduced to quantitatively indicate the conversion of a certain land type.

$$
C_{j}=2 \times \min \left(S_{j+}-S_{j j}, S_{+j}-S_{j j}\right)
$$

where $C_{j}=$ exchange capacity of the $\mathrm{j}$-th land use type

The sum of the net change and the exchange capacity is the total change of a certain land use type. The total change of the land use type is actually the sum of the transfer-out and transfer-in area.

\section{RESULTS}

This study was based on the land use data of 1978 and 2018. Land use type dynamics and land use transfer matrix are the main 
indicators. The land use change in Inner Mongolia Region in the past 40 years is the object of analysis.

\subsection{Land use interpretation results}

The land use data of 2018 was used to analyse the land use distribution in Inner Mongolia Region.

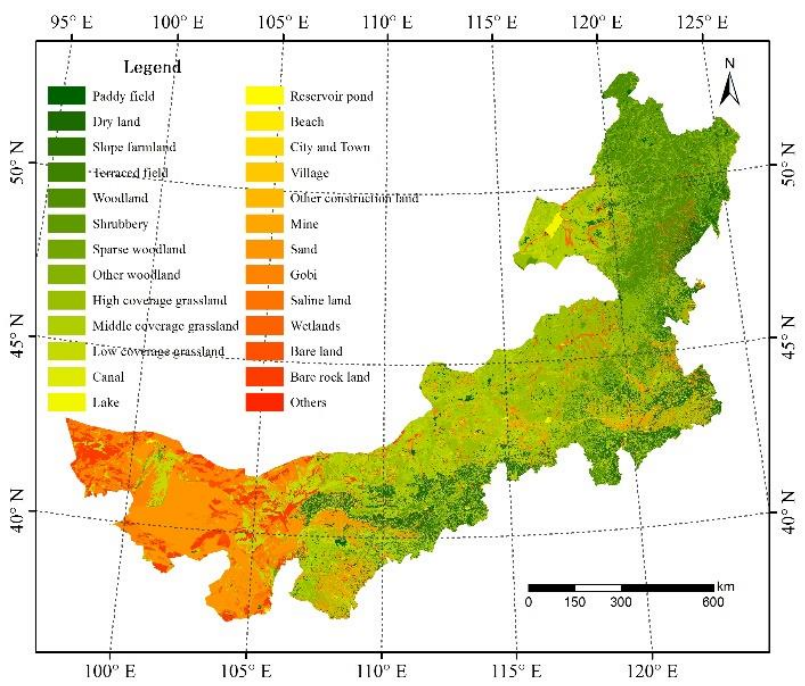

Figure 2.Land Use Map of Inner Mongolia Region in 1978

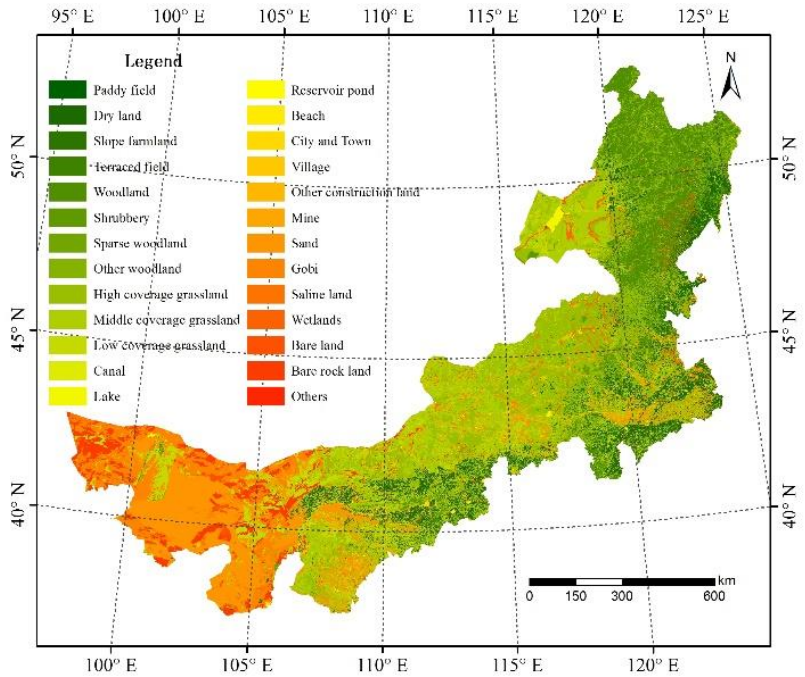

Figure 3.Land Use Map of Inner Mongolia Region in 2018

It was found that in 2018, the area of arable land in the Inner Mongolia was $115,600 \mathrm{~km}^{2}$ (accounting for $10.05 \%$ of the total area of the Inner Mongolia Region, the same below), the forest area was $165,900 \mathrm{~km}^{2}(14.42 \%)$, the grassland area was 525,200 $\mathrm{km}^{2}(45.65 \%)$, and the water area was $1.4210,000 \mathrm{~km}^{2}$ (accounting for 1.24\%), urban and rural, industrial, mining, and residential land area of $18,200 \mathrm{~km}^{2}$ (accounting for $1.59 \%$ ), unused land area of $314,100 \mathrm{~km}^{2}$ (accounting for 27.07\%), the land use structure varies greatly in different regions. Among them, cultivated land is mainly distributed in the central and eastern regions, woodland is mainly distributed in the eastern region, grassland is mainly distributed in the central and eastern regions, and sandy land, Gobi, bare rock land, and saline-alkali land in unused land are mainly distributed in the western region, and swampland is mainly distributed in the eastern region.

\subsection{Land use change rate analysis}

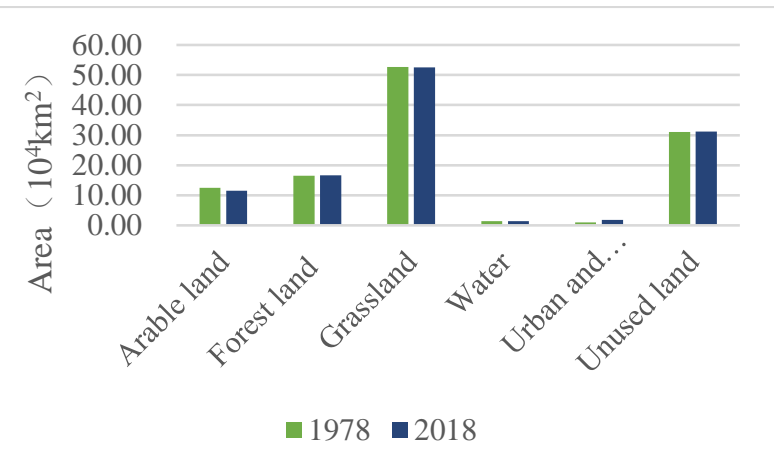

Figure 4. Comparison of land use area in 1978 and 2018

Table 1 Change rate of land use types in Inner Mongolia Autonomous Region from 1978 to 2018 (positive values increase, negative values decrease)

\begin{tabular}{|c|c|c|c|c|c|c|}
\hline \multirow{2}{*}{ Year } & \multicolumn{6}{|c|}{ Change rate of land use types (\%) } \\
\cline { 2 - 7 } & $\begin{array}{c}\text { Arable } \\
\text { land }\end{array}$ & $\begin{array}{c}\text { Forest } \\
\text { land }\end{array}$ & $\begin{array}{c}\text { Gras } \\
\text { slan } \\
\mathrm{d}\end{array}$ & Water & $\begin{array}{c}\text { Urban and } \\
\text { rural, } \\
\text { industrial, } \\
\text { mining } \\
\text { land }\end{array}$ & $\begin{array}{c}\text { Unu } \\
\text { sed } \\
\text { land }\end{array}$ \\
\hline $\begin{array}{c}1978- \\
2018\end{array}$ & -7.18 & 0.52 & - & 0.62 & 75.89 & 0.50 \\
\hline
\end{tabular}

From the analysis of the chart, it can be seen that the area of cultivated land has decreased overall, from $126,600 \mathrm{~km}^{2}$ to $115,600 \mathrm{~km}^{2}$, the land use change rate is $-7.18 \%$. The area of forest land has increased from $165,000 \mathrm{~km}^{2}$ to $165,900 \mathrm{~km}^{2}$, and the change rate is $0.52 \%$. The grassland area is reduced from $526,600 \mathrm{~km}^{2}$ to $525,200 \mathrm{~km}^{2}$, and the land use change rate is $0.27 \%$. The water area is increased from $14,100 \mathrm{~km}^{2}$ to 14,200 $\mathrm{km}^{2}$, and the change rate is $0.62 \%$. Residential land increased significantly, from $10,400 \mathrm{~km}^{2}$ in 1978 to $18,200 \mathrm{~km}^{2}$ in 2018 , an increase of $70,800 \mathrm{~km}^{2}$, and the change rate is $75.89 \%$. Unused land increased from $309,000 \mathrm{~km}^{2}$ to $31,114 \mathrm{~km}^{2}$, the rate of change is $0.5 \%$.

\subsection{Land Use Transfer Analysis}


Table 2. Land Use Transfer Matrix from 1978 to 2018 (Unit: 10,000 km²)

\begin{tabular}{|c|c|c|c|c|c|c|c|c|c|}
\hline & \multicolumn{6}{|c|}{2018} & \multirow[b]{2}{*}{ Total } & \multirow[b]{2}{*}{ Transfer out } \\
\hline & & Arable land & Forest land & Grassland & Water & $\begin{array}{l}\text { Urban and } \\
\text { rural, } \\
\text { industrial, } \\
\text { mining land }\end{array}$ & Unused land & & \\
\hline \multirow{8}{*}{1978} & Arable land & 9.54 & 0.59 & 1.60 & 0.09 & 0.21 & 0.43 & 12.46 & 2.92 \\
\hline & Forest land & 0.31 & 15.81 & 0.34 & 0.00 & 0.03 & 0.01 & 16.50 & 0.69 \\
\hline & Grassland & 1.53 & 0.14 & 50.05 & 0.05 & 0.32 & 0.58 & 52.66 & 2.61 \\
\hline & Water & 0.04 & 0.00 & 0.04 & 1.20 & 0.06 & 0.06 & 1.41 & 0.21 \\
\hline & $\begin{array}{l}\text { Urban and } \\
\text { rural, } \\
\text { industrial, } \\
\text { mining land }\end{array}$ & 0.00 & 0.00 & 0.00 & 0.00 & 1.03 & 0.00 & 1.04 & 0.00 \\
\hline & Unused land & 0.14 & 0.04 & 0.49 & 0.07 & 0.18 & 30.06 & 30.99 & 0.93 \\
\hline & Total & 11.56 & 16.59 & 52.52 & 1.42 & 1.82 & 31.14 & - & - \\
\hline & Transfer in & 2.02 & 0.78 & 2.47 & 0.22 & 0.79 & 1.08 & - & - \\
\hline
\end{tabular}

Table 3. Land use change from 1978 to 2018 (Unit: 10,000 $\mathrm{km}^{2}$ )

\begin{tabular}{|c|c|c|c|c|c|}
\hline $\begin{array}{c}\text { Land } \\
\text { Use }\end{array}$ & $\begin{array}{c}\text { Transfer } \\
\text {-in area }\end{array}$ & $\begin{array}{c}\text { Transfer } \\
\text {-out } \\
\text { area }\end{array}$ & $\begin{array}{c}\text { Total } \\
\text { chang } \\
\mathrm{e}\end{array}$ & $\begin{array}{c}\text { Exchang } \\
\text { e change }\end{array}$ & $\begin{array}{c}\text { Net } \\
\text { chang } \\
\mathrm{e}\end{array}$ \\
\hline $\begin{array}{c}\text { Arable } \\
\text { land }\end{array}$ & 2.02 & 2.92 & 4.94 & 4.05 & 0.89 \\
\hline $\begin{array}{c}\text { Forest } \\
\text { land }\end{array}$ & 0.78 & 0.69 & 1.47 & 1.38 & 0.09 \\
\hline $\begin{array}{c}\text { Grasslan } \\
\text { d }\end{array}$ & 2.47 & 2.61 & 5.08 & 4.94 & 0.14 \\
\hline Water & 0.22 & 0.21 & 0.43 & 0.42 & 0.01 \\
\hline $\begin{array}{c}\text { Urban } \\
\text { and } \\
\text { rural, } \\
\text { industria } \\
\text { l, mining } \\
\text { land }\end{array}$ & 0.79 & 0.00 & 0.79 & 0.00 & 0.79 \\
\hline $\begin{array}{c}\text { Unused } \\
\text { land }\end{array}$ & 1.08 & 0.93 & 2.01 & 1.85 & 0.15 \\
\hline
\end{tabular}

From the conversion table of the land use, the largest total land use change in Inner Mongolia Region from 1978 to 2018 was grassland, with a total change area of $50,800 \mathrm{~km}^{2}$, of which the area transferred in was $24,700 \mathrm{~km}^{2}$, mainly from cultivated land $\left(16,000 \mathrm{~km}^{2}\right)$, unused land $\left(0.49\right.$ million $\left.\mathrm{km}^{2}\right)$ and forest land $\left(30,400 \mathrm{~km}^{2}\right)$. The area transferred out of grassland was 26,100 $\mathrm{km}^{2}$, mainly transferred to cultivated land $\left(15,300 \mathrm{~km}^{2}\right)$, unused land $\left(50,800 \mathrm{~km}^{2}\right)$, urban and rural, industrial land $(0.32$ million $\mathrm{km}^{2}$ ), with a net change of $14,400 \mathrm{~km}^{2}$.

The largest total change was followed by cultivated land, with an area of transferred out of $29,200 \mathrm{~km}^{2}$ and an area of transferred in $20,200 \mathrm{~km}^{2}$, and the net change of cultivated land was 89,000 $\mathrm{km}^{2}$. The total change area of unused land was $20,100 \mathrm{~km}^{2}$, of which the transferred-in area was $10,800 \mathrm{~km}^{2}$, the transferred-out area was $9,300 \mathrm{~km}^{2}$, and the net change area was $15,00 \mathrm{~km}^{2}$. The total change area of woodland was $14,700 \mathrm{~km}^{2}$, of which the area of transferred in was $7,800 \mathrm{~km}^{2}$, the area of transferred out was $69,00 \mathrm{~km}^{2}$, and the net change area was $9,00 \mathrm{~km}^{2}$.

The total change area of urban and rural, industrial and mining land is $7,900 \mathrm{~km}^{2}$, of which the transferred-in area in was 7,900 $\mathrm{km}^{2}$, and the transferred-out area was 0 . The total change area of water area is 4300 million $\mathrm{km}^{2}$, of which the transfer-in area wass $2,200 \mathrm{~km}^{2}$, and the transfer-out area was $2,100 \mathrm{~km}^{2}$, with a net change area of 100 million $\mathrm{km}^{2}$.

\section{RESULTS}

(1) Through the analysis of the spatial distribution of land use in Inner Mongolia Region in 2018, it was found that the land use type in different regions is very different. Grassland and arable land are mainly distributed in the central region, and grassland, forest and arable land are mainly distributed in the eastern region. Unused land is mainly distributed in the western region. The largest area in Inner Mongolia Region is grassland, which accounts for $45.65 \%$ of the total area, followed by unused land(27.07\%), forest land(14.42\%), cultivated land(10.05\%), urban and rural areas, industrial and mining land(1.59\%), and water area $(1.24 \%)$

(2)The land use changes in the Inner Mongolia Region in the past 40 years was analysed. It was found that the area of cultivated land has decreased by 0.9 thousand $\mathrm{km}^{2}$, the area of forest land has changed less, increased by 0.09 million $\mathrm{km}^{2}$, and the area of grassland has decreased by $14,400 \mathrm{~km}^{2}$. The area of water changed less with an increase of 0.01 million $\mathrm{km}^{2}$, while urban and rural, industrial and mining land continue to increase, from 1978 to 2018 , with a total area of $7,800 \mathrm{~km}^{2}$. Unused land increased by $11,500 \mathrm{~km}^{2}$. It was shown that after 40 years of development, human activity in the Inner Mongolia Region has increased urban and rural, industrial and mining land, but at the same time, the policy of returning farmland to forests to protect the environment has achieved significant results. 


\section{ACKNOWLEDGEMENTS}

This work was supported by the National Keypoint Research and Invention Program of the Thirteenth Five-Plan (2017YFB0504105), and the National Natural Science Foundation of China (No. 41601569). The authors would like to express appreciations to colleagues in our department for their valuable comments and other helps.

\section{REFERENCES}

Deepak Khare, Diptendu Patra, et. Al. Impact Of Landuse/land cover change on run-off in a catchment of Narmada river in India [J]. Appl Geomat, 2015(7):23-35.

Deepak Khare, Diptendu Patra, et. Al. Impact Of Landuse/land cover change on run-off in a catchment of a hydro power project [J]. Appl Water Science, 2017(7):787-800.

Ashraf M. Dewan, Yasushi Yamaguchi, Using remote sensing and GIS to detect and monitor land use and land cover change in Dhaka Metropolitan of Bangladesh during 1960-2005 [J], Environment Monitor Assess, 2009(150):237-249.

I.I. Abbas, K.M. Muazu, J.A. Ukoje, Mapping Land Use-land Cover and Change Detection in Kafur Local Government, Katsina, Nigeria (1995-2008) Using Remote Sensing and Gis [J], Research Journal of Environmental and Earth Sciences, 2010, 2(1):6-12.

I.I. Abbas. An overview of land cover changes in Nigeria, 1975 - 2005 [J]. Journal of Geography and Regional Planning, 2009, 2(4):062-065.

Aramde Fetene, Thomas Hilker, et. Al. Detecting Trends in Landuse and Landcover Change of Nech Sar National Park, Ethiopia [J], Environmental Management (2016) 57:137-147.

Sani Abubakar Mashi-Hassana Suleiman Shuaibu. People and sustainable land management: assessment of stakeholders knowledge of the nature of landuse/cover change in Abuja, Nigeria [J], GeoJournal, 2018(83):545-562

P. KOTOKY, M. K. DUTTA, G. C. BORAH. Changes in Landuse and Landcover along the Dhansiri River Channel, Assam - A Remote Sensing and GIS Approach [J], JOURNAL GEOLOGICAL SOCIETY OF INDIA, 2012(79):61-68.

MENG Jijun, WU Xiuqin, LI Zhengguo. Landuse/landcover changes in Zhangye oasis of Hexi Corridor, Journal of Geographical Sciences, 2003, 13(1):71-75.

YAO Ziyan, ZHANG Lijuan, et. Al. The basic characteristics and spatial patterns of global cultivated land change since the $1980 \mathrm{~s}$ [J], J. Geogr., 2017, 27(7): 771-785.

Liu Jiyuan, Ning Jia, Kuang Wenhui, Xu Xinliang, Zhang Shuwen, Yan Changzhen, Li Rendong, Wu Shixin, Hu Yunfeng, Du Guoming, Chi Wenfeng, Pan Tao, and Ning Jing. Spatiotemporal pattern and new characteristics of China's land use change in 2015 [J] .Acta Geographica Sinica, 2018,73 (05): 789-802.

Gao Xiaoyu, Cheng Weiming, Wang Nan, Liu Yiyi, Ma Ting, Chen Yinjun, Zhou Chenghu. Analysis of the spatio-temporal changes of cultivated land in China from 1990 to 2015 based on geomorphological zoning [J]. Journal of Geographical Sciences, 2019, 29 (02) : 180-196.

Zhai Jun, Shao Qinqin, Liu Jiyuan. Impact of Land Use / Cover Change on Air Temperature Change in Inner Mongolia Plateau [J]. Journal of Natural Resources, 2014, 29 (06): 967-978.

Tong Siqin. Study on the Spatial and Temporal Evolution and Prediction of Meteorological Drought in the Inner Mongolia Region under the Background of Climate Change [D]. Northeast Normal University, 2019.

Jiang Ling, Xiao Yan, Rao Enming, Wang Liyan, Ouyang Zhiyun. Impact of Inner Mongolia Land Use Change on Ecosystem Wind and Sand Fixation Function [J] .Acta Ecologica Sinica, 2016,36 (12): 3734-3747. 